\title{
Nitrogen conversion and apparent intestinal amino acid absorption in young bulls fed isonitrogenous diets with different nitrogen sources
}

\author{
J. Kowalczyk and Teresa Żebrowska \\ The Kielanowski Institute of Animal Physiology and Nutrition, \\ Polish Academy of Sciences \\ 05-110 Jablonna, Poland
}

(Received 6 April 1998; accepted 24 June 1998)

\section{ABSTRACT}

The experiment was carricd out on 10 bulls of about $120 \mathrm{~kg}$ live weight equipped with rumen cannulas and re-entrant cannulas in the proximal duodcnum and terminal ileum. The bulls were given a diet of maize whole plant meal, potato starch and mincral mixture. The diet was supplemented for group I with groundnut oilmeal $(60 \%$ of dietary $N)$, for group II with groundnut oilmcal $(10.5 \%$ dietary $\mathrm{N})$ and urca $(48 \%$ of dietary $\mathrm{N})$, and for group III with urea ( $58 \%$ dietary $\mathrm{N})$. Diets I, II and III contained, according to the INRA system, 15\% CP in DM; 234, 196, $186 \mathrm{~g}$ PDIN; 227, $158,145 \mathrm{~g}$ PDIT, and $2.14,2.11,2.11 \mathrm{UFV}$, respectively. Daily fced intakc was $2.25 \mathrm{~kg}$.

The ammonia- $\mathrm{N}$ level in the rumen fluid $2 \mathrm{~h}$ after feeding was $8.2,15.1$ and $24.5 \mathrm{mg} / 100 \mathrm{ml}$ in animals of groups I, II and III, respectively. The amount of N entering the duodenum was $20.1 ; 22.1$ and $18.0 \mathrm{~g}$, leaving the ilcum $9.7,10.4$ and $7.3 \mathrm{~g} /$ day $/ \mathrm{kg}$ of feed intake, in the respective groups. The apparent duodenal- $\mathrm{N}$ absorption from the small intestine was 52,53 and $59 \%$, respectively.

Total amino acids (g/day/ $\mathrm{kg}$ feed) ingested with fecd cqualled 128,62 and 49 ; entering the duodenum 107, 113 and 92; leaving the ileum 43, 48 and 32; absorbed from the small intestine 64, 65 and 60 in groups I, II and III, respectively. The apparent intestinal absorption of most amino acids entering the duodenum was from 50 to $70 \%$ in all groups, but absorption of cysteine was markedly lower, $25-40 \%$. The amount of lysine absorbed from the small intestine in group I was similar to the amount ingested, but exceeded this amount by 2.4 and 3 times in groups II and III. Absorption of methionine was two times higher, indicating considerable conversion of dietary N in group II and III into microbial amino acids.

KEY WORDS: amino acid, absorption, intestine, nitrogen source, ruminant 


\section{INTRODUCTION}

The amount of amino acids absorbed in the small intestine of ruminants depends on the quality and amount of ingested protein and its degradability in the rumen as well as on the source of energy that is easily available to microorganisms in the rumen (Ørskov, 1992; Pająk et al., 1992; Mebjcesh ct al., 1996; van Straalen ct al., 1997). Feed additives or treatment protecting protein from rumen degradation and technological feed processing also affect ileal amino acid digestibility (Kowalczyk and Otwinowska, 1982; Benchaar et al., 1994; Waghorn et al., 1994).

The objective of the present study was to estimate the amount of amino acids leaving the abomasum and their apparent digestibility in the small intestine of young bulls fed an isonitrogenous ration, but with different amounts of amino acids and non-protein nitrogen proportions.

\section{MATERIAL AND METHODS}

The experiment was carried out on 10 young Black-and-White bulls of about $120 \mathrm{~kg}$ liveweight equipped with permanent simple cannula into the rumen and with re-entrant cannulas situated at the proximal duodenum and terminal ileum.

The bulls were divided into three groups and given a basic diet of maize whole plant meal, potato starch and mineral mixture. The dict was supplemented for group I with groundnut oilmeal $(60 \%$ of dietary $\mathrm{N})$, for group II with groundnut oilmeal $(10.5 \%$ dietary $N)$ and urea $(48 \%$ of dietary $N)$, and for group III (4 animals) with urea ( $58 \%$ of dietary $\mathrm{N})$. The dietary components and chemical composition are presented in Table 1. Diets I, II and III contained, according to the INRA (1989) system, about 15.5\% CP in DM; 234, 196, 186 g PDIN; 227, 158, $145 \mathrm{~g}$ PDIE; and 2.14, 2.11, 211 UFV in $1 \mathrm{~kg}$ of the respective diets. Daily feed intake was $2.25 \mathrm{~kg}$ given in two equal portions at $7.30 \mathrm{a} . \mathrm{m}$. and $4.30 \mathrm{p} . \mathrm{m}$.

After feeding with the respective dicts for two wecks the animals were housed in metabolic cages and a digesta sampling period lasting 3 consecutive days was started. Samples of rumen liquor were taken before and 2 and $4 \mathrm{~h}$ after the morning feeding for determination of $\mathrm{pH}$, ammonia- $\mathrm{N}$ and volatile fatty acids. The digesta flowing into the duodenum and leaving the ileum was measured directly continuously in a 3-day collection and returned into the duodenum or ilcum after taking samples of $3 \%$ from the duodenum and $5 \%$ from ileum for analysis. The daily bulked samples of digesta were analysed for $\mathrm{pH}$, ammonia- $\mathrm{N}$ in fresh material, while the samples for determination of DM, total N, VFA and amino acid composition were frozen until analysis.

$\mathrm{pH}$ was measured potentiometrically, ammonia-N with the Conway (1962) diffusion method, total volatile fatty acids by stcam distillation from solutions acidi- 
TABLE 1

Components and chemical composition of rations, \%

\begin{tabular}{rrr} 
& Group & \\
\hline I & II & III
\end{tabular}

Feeds

$\begin{array}{lrrc}\text { dchydrated maize (whole plants) } & 76.0 & 76.0 & 76.0 \\ \text { groundnut oilmeal } & 18.0 & 3.0 & - \\ \text { potatoe starch } & 4.5 & 17.2 & 19.7 \\ \text { mineral mixture } & 1.5 & 1.5 & 1.5 \\ \text { urea } & - & 2.3 & 2.8\end{array}$

Chemical composition

$\begin{array}{lrrr}\text { dry matter } & 92.59 & 92.27 & 92.21 \\ \text { ash } & 5.98 & 4.99 & 4.80 \\ \text { crudc protein } & 15.98 & 15.48 & 15.31 \\ \text { protcin from natural feeds } & 15.98 & 8.05 & 6.45 \\ \text { urea } & - & 2.55 & 3.04 \\ \text { ether extract } & 2.13 & 1.97 & 1.94 \\ \text { crude fibre } & 14.79 & 13.59 & 13.35 \\ \text { N-free exiractives } & 61.12 & 68.85 & 70.42\end{array}$

fied with sulphuric acid, amino acids in feeds and digesta were determined with a Beckman Unichrom amino acid analyser after previous $6 \mathrm{~N} \mathrm{HCl}$ hydrolysis of samples, methionine and cysteine after previous oxidation with performic acid.

\section{RESULTS}

The $\mathrm{pH}$ values, ammonia- $\mathrm{N}$ and volatile fatty acid concentrations in rumen liquor indicated that the nutrients entered normal metabolic pathways (Table 2).

TABELA 2 Ammonia- $\mathrm{N}(\mathrm{mg} / 100 \mathrm{~mL})$, VFA $(\mathrm{mmol} / \mathrm{L})$ concentration and $\mathrm{pH}$ value in the rumen liquor, $(0-$ before feeding, 2 and $4 \mathrm{~h}$ after feed administration)

\begin{tabular}{|c|c|c|c|c|c|c|c|c|c|}
\hline \multirow{4}{*}{ Component } & \multicolumn{9}{|c|}{ Group } \\
\hline & \multicolumn{3}{|c|}{ I } & \multicolumn{3}{|c|}{ II } & \multicolumn{3}{|c|}{ III } \\
\hline & \multicolumn{6}{|c|}{ sampling time } & & & \\
\hline & 0 & 2 & 4 & 0 & 2 & 4 & 0 & 2 & 4 \\
\hline $\mathrm{NH}_{3}-\mathrm{N}, \mathrm{mg} / 100 \mathrm{~mL}$ & 8.1 & $8.2^{\mathrm{A}}$ & 4.1 & 6.1 & $15.1^{\mathrm{B}}$ & 5.8 & 6.0 & $24.5^{\mathrm{c}}$ & 5.0 \\
\hline $\mathrm{VFA}, \mathrm{mmol} / \mathrm{L}$ & 73.2 & 87.6 & $79.2^{\mathrm{a}}$ & 78.6 & 90.0 & $89.5^{\mathrm{b}}$ & 80.4 & 94.4 & $94.6^{b}$ \\
\hline $\mathrm{pH}$ & 6.96 & 6.08 & 6.57 & 6.67 & 6.42 & 6.23 & 7.06 & 6.43 & 6.06 \\
\hline
\end{tabular}

$\mathrm{A}, \mathrm{B}, \mathrm{C}-\mathrm{P}<0.05 ; \mathrm{a}, \mathrm{b},-\mathrm{P}<0.05$ between the groups 2 or $4 \mathrm{~h}$ after feeding 
The ammonia level in the rumen liquor at $2 \mathrm{~h}$ after feeding diets containing urea increased $(P<0.01)$ as the amount of urea in the dict rose. Volatile fatty acids increased slightly $(\mathrm{P}>0.05)$, corresponding to the rise in the level of easily fermentable starch.

In all of the groups the $\mathrm{pH}$ of duodenal and ileal digesta was similar and ranged from 2.2 to 2.5 , and from 7.9 to 8.2 , respectively, indicating normal function of the abomasum and small intestine. The amount of ammonia- $\mathrm{N}$ flowing with the digesta into the duodenum was small in animals of all groups, about $0.5 \mathrm{~g} / \mathrm{kg}$ ingested ration.

The apparent digestibility of dry matter in the forestomachs was highest in group III, about $46 \%(\mathrm{P}<0.05)$ and lowest in group II, about $31 \%$, disappearance of total nitrogen in the forestomachs was most pronounced in animals of group III, $27 \%(\mathrm{P}>0.05$ ), least in group II, 24\% (Table 3).

TABLE 3

Dry matter and total- $\mathrm{N}$ ingested, entering duodenum and leaving ileum ( $\mathrm{g} /$ day $/ \mathrm{kg}$ feed intake), and their apparent absorption in the forestomachs or in the small intestine, $\%$

\begin{tabular}{|c|c|c|c|c|}
\hline & \multicolumn{4}{|c|}{ Group } \\
\hline & & $\mathrm{I}$ & II & III \\
\hline \multirow[t]{2}{*}{ lngested: } & dry matter & 923 & 923 & 922 \\
\hline & total-N & 25.6 & 24.8 & 24.5 \\
\hline \multirow[t]{2}{*}{ Entering duodenum: } & dry matter & $519^{A}$ & $636^{\mathrm{B}}$ & $494^{\mathrm{A}}$ \\
\hline & total-N & 20.1 & 22.1 & 18.0 \\
\hline \multirow[t]{2}{*}{ Leaving ileum: } & dry matter & $408^{A}$ & $484^{\mathrm{B}}$ & $348^{\circ}$ \\
\hline & total-N & $9.7^{\mathrm{a}}$ & $10.4^{\circ}$ & $7.3^{b}$ \\
\hline \multicolumn{5}{|l|}{ Apparent digestion: } \\
\hline \multirow[t]{2}{*}{ in forestomachs } & dry matter & $43.8^{\mathrm{b}}$ & $31.1^{\mathrm{a}}$ & $46.4^{b}$ \\
\hline & total-N & 25.4 & 23.9 & 26.5 \\
\hline \multirow[t]{2}{*}{ in small intestinc } & dry matter & $21.5^{\mathrm{a}}$ & $23.9^{\mathrm{a}}$ & $29.5^{\mathrm{h}}$ \\
\hline & total-N & $52.0^{\mathrm{a}}$ & $52.9^{a}$ & $59.4^{b}$ \\
\hline
\end{tabular}

a, b, c- $-\mathrm{P}<0.05 ; \mathrm{A}, \mathrm{B}, \mathrm{C}-\mathrm{P}<0.01$

The amount of total-N passing from the abomasum to duodenum (Table 3), expressed in grams per kilogram of ingested ration, was largest in bulls of group II and lowest in those from group III $(\mathrm{P}>0.05)$. The apparent digestibility of total-N and dry matter in the small intestine was highest in animals of group III and lowest in group I $(\mathrm{P}<0.05)$. The total amount of amino acids flowing to the duodenum (Table 4) in group Il was similar to that in group I in spite of the bulls of this group ingesting considerably less $(\mathrm{P}<0.01)$ amino acids than those in group I. In group I, 
TABLE 4

Total amino acids ingested, entering duodenum, leaving ileum ( $\mathrm{g} / \mathrm{day} / \mathrm{kg}$ of feed), and apparcnt absorption from small intestinc, \%

\begin{tabular}{ccc} 
Group \\
\hline I & II & III \\
$128^{\mathrm{A}}$ & $62^{\mathrm{Ba}}$ & $49^{\mathrm{Bb}}$ \\
$107^{\mathrm{a}}$ & $113^{\mathrm{a}}$ & $92^{\mathrm{b}}$ \\
$43^{\mathrm{a}}$ & $48^{\mathrm{a}}$ & $32^{\mathrm{b}}$
\end{tabular}

Absorption of amino acids in intestine, $g$

Aminoacids entering duodenum related to ingested with leed, $\%$

$64 \quad 65 \quad 60$

Amino acids, g/day $/ \mathrm{kg}$ of feed

ingested with feed

entering the duodenum

leaving ileum

$107^{\circ}$

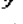

$32^{\mathrm{b}}$

Absorption of aminoacids in intestinc, \%

Proportion of amino acids absorbed in

small intestine to ingested, $\%$

$84 \quad 182 \quad 187$

$\begin{array}{lll}60 & 57 & 65\end{array}$

$\mathrm{a}, \mathrm{b}-\mathrm{P}<0.05 ; \mathrm{A}, \mathrm{B}-\mathrm{P}<0.01$

total amino acids flowing with duodenal digesta were $16 \%$ less than ingested, $82 \%$ less in group II, and $87 \%$ more in group III.

The apparent absorption of total amino acids from the intestine $(\mathrm{g} / \mathrm{day} / \mathrm{kg} \mathrm{fecd})$ was slightly higher in groups I and II than in group III $(P>0.05)$, but when expressed as a per cent of the amount of amino acids entering the duodenum, it was highest in group III and lowest in the animals of group II (Table 4). The amount of total amino acids apparently absorbed from the small intestine compared with their intake was $50 \%$ less in group I, but 4 and $22 \%$ more than ingested in group II and III (Table 5).

Apparent absorption from the small intestine of most individual amino acids (Table 5) was from 50 to $70 \%$ in all groups but absorption of cystine was markedly lower, $25-40 \%$. The amount of lysine apparently absorbed from the small intestine in group I was similar to the amount ingested, but in group II and III exceeded its intake by 2.4 and 3 times. $\Lambda$ bsorption of methionine in groups II and III was twice as high, but in group I, about $20 \%$ less than ingested.

\section{DISCUSSION}

The pattern of changes of $\mathrm{pH}$ values as well as the concentration of ammonia and volatile fatty acids in ruminal, duodenal and ileal digesta reflected the diet compositions and indicated that the digestive tracts of the animals in all of the groups were functioning normally. The significant increase in the ammonia con- 
TABLE 5

The apparent absorption of individual amino acids from the small intestine and their proportion to ingested

\begin{tabular}{|c|c|c|c|c|c|c|}
\hline \multirow{3}{*}{ Amino acid } & \multicolumn{3}{|c|}{$\begin{array}{l}\text { Absorbed from intestine: } \\
\text { leaving abomasum, } \%\end{array}$} & \multicolumn{3}{|c|}{$\begin{array}{c}\text { Absorbed: } \\
\text { ingestcd with feed, } \%\end{array}$} \\
\hline & \multicolumn{3}{|c|}{ group } & \multicolumn{3}{|c|}{ group } \\
\hline & I & II & III & I & II & III \\
\hline Asp & 62 & 60 & 68 & 51 & 126 & 155 \\
\hline Thr & 57 & 54 & 62 & 77 & 144 & 157 \\
\hline Ser & 57 & 55 & 66 & 49 & 106 & 138 \\
\hline Glu & 61 & 59 & 66 & 38 & 88 & 105 \\
\hline Pro & 49 & 50 & 62 & 34 & 60 & 77 \\
\hline Gly & 52 & 50 & 61 & 43 & 96 & 123 \\
\hline Ala & 58 & 58 & 64 & 66 & 118 & 118 \\
\hline Val & 55 & 51 & 59 & 56 & 100 & 105 \\
\hline Ile & 60 & 57 & 62 & 67 & 129 & 126 \\
\hline Leu & 62 & 59 & 69 & 53 & 88 & 100 \\
\hline Tyr & 69 & 64 & 70 & 66 & 132 & 153 \\
\hline Phe & 63 & 58 & 66 & 51 & 100 & 120 \\
\hline Lys & 68 & 66 & 72 & 109 & 240 & 293 \\
\hline His & 57 & 54 & 65 & 42 & 85 & 107 \\
\hline Arg & 68 & 65 & 72 & 30 & 85 & 126 \\
\hline Cys & 29 & 24 & 40 & 23 & 32 & 57 \\
\hline Met & 67 & 69 & 71 & 78 & 151 & 149 \\
\hline $\operatorname{Trp}$ & 47 & 44 & 50 & 53 & 117 & 128 \\
\hline Total $\Lambda \Lambda$ & 60 & 57 & 65 & 50 & 104 & 132 \\
\hline
\end{tabular}

centration in the rumen liquor $2 \mathrm{~h}$ after feeding the animals of group II and III was caused by, respectively, the high content of rapidly hydrolysable urea in the diet (III, $58 \%$; and II, $48 \%$ of urea origin nitrogen) delivering ammonia for growth of microorganisms. Only a small part of the ammonia produced in the rumen reached the duodenum, suggesting that most of it was converted into microbial protein or absorbed in the forestomachs.

The apparent digestibility of dry matter in the reticulo-rumen differed among the groups, ranging from $31 \%$ in group II to $46 \%$ in group III. The reason for such a wide variation is difficult to explain on the basis of the data obtained from the experiment. The results of respective nitrogen digestion were more consistent and ranged from 24 to $27 \%$ despite expectations that nitrogen from the forestomachs of animals fed diets with urea would disappear at a faster rate. The possible explanation may be that nitrogen of urea origin was effectively incorporated into microbial protein. 
Data concerning the apparent digestibility of nitrogen in the forestomachs found in numerous papers usually oscillates in a wide range between -30 to $+30 \%$ (Otwinowska and Kowalczyk, 1985; Waltz et al., 1989; Becver ct al., 1990; Coomer et al., 1993). The reason for such wide dispersion of nitrogen apparent digestibility is the level and quality of nitrogen compounds in the diet. Negative values of digestibility are usually obtained when intake of nitrogen compounds is low and the inflow of nitrogen into the rumen with saliva and across the rumen wall from the blood prevails over its absorption from the reticulo-rumen. In cases of excess dictary nitrogen intake the opposite situation occurs and apparent digestibility in the reticulo-rumen is positive. In our experiment, with a large proportion of casily degradable groundnut protein and non-protein nitrogen in the diet, the apparent digcstibility of nitrogen in the reticulo-rumen was rather high in all groups of animals, reaching a value of about $25 \%$, suggesting excess nitrogen intake.

Apparent digestibility of dry matter in the small intestine increased with the level of urea in the dict, rising from $22 \%$ in group I to $30 \%$ in group III and corresponded to the digestibility of nitrogen (52 to $59 \%$ ) in this part of the digestive tract (Table 3). Waltz et al. (1989) and Becver et al. (1990) reported a significant effect of protein sourcc (maize silage, fish meal, soyabean meal, heated soyabean meal, maize gluten meal, blood meal or combinations of them) on intestinal dry matter and nitrogen digestibility in cattle fed diets with different high protein feeds. Protein of lower digestibility in the reticulo-rumen, e.g. fish meal, blood meal or heated soyabean meal was usually more digestible in the small intestine. A similar cffect was found in our experiment with young bulls fed groundnut oilmeal or its substitute, urea.

The similar amounts of total amino acids entering the duodenum of animals in groups I and II suggest considerable conversion of urea nitrogen into microbial amino acids in bulls of group II. The smallest amount of total amino acids flowed through the duodenum of animals fed the diet in which $58 \%$ of nitrogen was in the form of urea and which supplied the lowest amount of amino acids. The reason for this was probably that the proportion of non-protein nitrogen in diet III exceeded the capability of the rumen population to convert it into microbial protein. The higher level of ammonia in those animals $2 \mathrm{~h}$ after feeding supports this explanation because a higher rumen ammonia level favours absorption of this compound from the rumen more than its conversion into bacterial protein. However, the efficiency of amino acid absorption from the small intestine of animals with the smallest amount of amino acids entering the duodenum was higher than in the other groups, perhaps due to the higher efficiency of enzymatic protein digestion.

The amount of total and individual amino acids apparently absorbed from the small intestine compared to the intake of amino acids, particularly of lysine which exceeded intake 2.4 and 3 times, and methioninc-about two times (Table 5), con- 
firms the relatively high conversion of non-protein nitrogen into amino acids even at high proportions, above $50 \%$, of urea-nitrogen in the diet.

Apparent absorption from the small intestine of most of individual amino acids (Table 5) was from 50 to $70 \%$ in all groups, but absorption of cystine was markedly less. The range of absorption of individual amino acids estimated in our cxperiment is similar to reported by other authors (Waltz et al., 1989; Hussein et al., 1991; Kerry et al., 1992; Cecava et al., 1993; Benchaar et al., 1994 a,b). The low apparent absorption of cysteine from the small intestine found in our experiment (Table 5) agrees with the findings of other authors (Bowman and Paterson, 1988; Van Bruchem et al., 1989; Cecava et al., 1993; Schröder et al., 1997; Żebrowska et al., 1997). The reason for this is not clear, however. A possible partial explanation could be that endogenous cysteine may be delivered to the small intestine with digestive enzymes such as trypsin and chymotrypsin, which contain three to four times more cysteine than most feed or bacterial proteins (Tamminga, 1979) or from desquamation of the epithelium, which contains a rather high level of cysteine (Żebrowska and Kowalczyk, 1990).

It can be concluded that replacement of $50 \%$ of dietary nitrogen by urea nitrogen in diets for growing bulls has no adverse effect on the amount of amino acids absorbed from the small intestine when the diet contains enough energy easily available for bacteria. With $60 \%$ of dietary nitrogen in the form of urea, the amount of amino acids entering the duodenum is reduced but their digestibility in the small intestine is elevated. Nitrogen compounds of diets containing a high proportion of non-protein nitrogen are converted into microbial protein to a substantial extent, with a concomitant, significant increase of lysine and methionine entering the duodenum over their amount in the ingested feed.

\section{REFERENCES}

Benchaar C., Moncoulon R., Bayourthe C., Vernay M., 1994 a. Effect of a supply of raw or extruded white lupin seeds on protein digestion and amino acid absorption in dairy cows. J. Anim. Sci. $72,492-501$

Benchaar C., Vernay M., Bayourthe C., Moncoulon R., 1994 b. Effects of extrusion of whole horse beans on protein digestion and amino acid absorption in dairy cows. J. Dairy Sci. 77, 1360-1371

Becver D.E., Gill M., Dawson J.M., Buttery P.J., 1990. The effect of fish meal on the digestion of grass silage by growing cattle. Brit. J. Nutr. 63, 489-502

Bowman J.G.P., Paterson J.A., 1988. Evaluation of corn gluten feed in high-energy diets for sheep and cattle. J. Anim. Sci. 66, 2057-2070

Cecava M.J., I Jancock D.I., Parker J.F., 1993. Effect of zinc-treated soybean meal on ruminal fermentation and intestinal amino acid flows in steers fed corn-silage based diets. J. Anim. Sci. 71, 3423-3431 
Coomer J.C., Amos H.E., Froetschel M.A., Ragland K.K., Williams C.C., 1993. Effect of supplemental protein source on ruminal fermentation, protein degradation and amino acid absorption in steers and on growth and feed efficiency in steers and heifers. J. Anim. Sci. 71, 3078-3086

Conway E.J., 1957. Microdiffusion Analysis and Volumetric Error. Crosby Lackwood, London

Husscin H.S., Jordam M.R., Stern M.D., 1991. Rumen protein metabolism and intestinal amino acid utilization as affected by dietary protein and carbohydrate sources in sheep. J. Anim. Sci. 69, 2134-2146

INRA, 1989. Ruminant Nutrition. Recommended Allowances and Feed Tables. R. Jarrige (Editor). INRA. John Libbey, London-Paris

Kerry C.M., Amos H.E., Froetschel M.A., 1992. Effects of supplemental protein source on intraruminal fermentation, protein degradation, and amino acid absorption. J. Dairy Sci. 76, 514-524

Kowalczyk J., Otwinowska A., 1982. Didestion of formaldehyde-treated rapeseed protein in the intestinal tract of young bulls. Arch. Ticrernähr. 32. 755-761

Mebjecsh S.J., Aricli A., Bruckental I., Zamwell S., Tagari H., 1996. Effect of type of protein supplementation on duodenal amino acid flow and absorption in lactating cows. J. Dairy Sci. $79,1792-1801$

Otwinowska A., Kowalczyk J., 1985. The effect of amount of urea in the diet on the contents of amino acids and other components of duodenal digesta in young bulls. Arch. Tierernähr. 35, 339-349

$\varnothing$ rskov E.R., 1992. Protein Nutrition in Ruminants. Academic Press, London

Pająk J.J., Żebrowska T., Zebrowska H., 1992. Protein content in the diet for fattening lambs. 2. The chemical and amino acid composition of the body and utilization of amino acids apparently absorbed in the small intestine. J. Anim. Feed Sci. 1, 27-36

Schröder A., Südekum K.H., Brandt M., Gabel M., 1997. Disappearance of amino acids from the gastro intestinal tract of dairy cows fed soyabean meal or fish meal diets. J. Anim. Feed Sci. 6, $53-69$

Tamminga S., 1979. Protein degradation in the forestomschs of ruminant. J. Anim. Sci. 49, 16151630

Van Bruchem J., Bongers L.J.G.M., Lammers-Wienhoven S.C.W., Bangma G.A., Van Adrichem P.W.M., 1989. Apparent and true digestibility of protein and amino acids in the small intestine of sheep as related to the duodenal passage of protein and non-protein dry matter. Livest. Prod. Sci. 23, 317-327

van Straalen W.M., Odinga J.J., Mosert W., 1997. Digestion of feed amino acids in the rumen and small intestinc of dairy cows measured with nylon bag techniques. Brit. J. Nutr. 77, 83-97

Waghorn G.C., Shelton I.D., McNabb W.C., McCutcheon S.N., 1994. Effect of condensed tannins in Lothus pedinculatus on its nutritive value for sheep. 2. Nitrogenous aspects. J. Agric. Sci., Camb. 123, 109-119

Waltz D.M., Stern M.D., Illg D.J., 1989. Effect of numinal protein degradation of blood meal and feather meal on the intestinal amino acid supply to lactating cows. J. Dairy Sci. 72, 1509-1518

Żebrowska T., Kowalczyk J., 1990. Nitrogen secretion into isolated loopsof the small intestine in conscious sheep. J. Anim. Physiol. Anim. Nutr. 65, 133-139

Żebrowska T.. Długołęcka Z., Pająk J.J., Korczyński W., 1997. Rumen degradability of concentrate protein, amino acids and starch, and their digestibility in the small intestine of cows. J. Anim. Feed Sci. 6, 451-470 


\section{STRESZCZENIE}

Konwersja azotu i wchłanianie aminokwasów w jelicie cienkim buhajków żywionych dawkami izoazotowymi o zróżnicowanych źródłach azotu

Doświadczenie przeprowadzono na 10 buhajkach o masic ciała około $120 \mathrm{~kg}$ z. trwalymi przetokami do żwacza oraz mostkowymi w początkowym odcinku dwunastnicy przed ujściem przewodu źółciowo-trzustkowego oraz na końcu jelita biodrowego. Zwierzęta otrzymywały dawkę złożoną z rozdrobniolego suszu z całych roślin kukurydzy, skrobi ziemniaczanej i mieszanki mineralnej. Dawkę uzupełniono w grupie I śrutą arachidową (60\% azotu dawki), w drugiej - poekstrakcyjną śrutą arachidową ( $10,5 \%$ azotu dawki) i mocznikicm ( $48 \%$ azotu dawki), w III - mocznikiem (58\% azotu dawki). Dawki I, II i III zawierały, zgodnie z systemem INRA, 15\% białka ogólnego w suchej masie; 234, 196 i 186 g BTJN; 227, 158 i 145 BTJE oraz 2,14; 2,11 i 2,11 JPŻ. Dzienne pobranie paszy wynosiło około $2.25 \mathrm{~kg}$.

Poziom $\mathrm{NH}_{3}-\mathrm{N}$ w plynnej treści żwacza wynosił 8,$2 ; 15,1$ i $24,5 \mathrm{mg} / 100 \mathrm{ml}$ u zwierząt z grup I, II i IIl, odpowiednio. Ilość azotu ogólnego przechodząca do dwunastnicy wynosiła, odpowiednio w kolejnych grupach, 20,1:22,1 i 18,0 g, a opuszczającego jelito biodrowe 9,$7 ; 10,4$ i 7,3 g/dzień/ $/ \mathrm{kg}$ pobranej paszy. Pozorne wchłanianie azotu w jelicie cienkim obliczone w odniesieniu do jlości azotu wpływającego $z$ treścią do dwunastnicy wynosiło 52,53 i $59 \%$ w kolejnych grupach.

Suma aminokwasów pobranych z paszą (g/dzień/kg paszy) wynosiła $128,62 \mathrm{i} 49 \mathrm{~g}$; przechodzących do dwunastnicy 107,113 i $928 \mathrm{~g}$, opuszczjących jelito biodrowe $64,65 \mathrm{i} 60 \mathrm{~g}$, odpowiednio w kolejnych grupach. Pozorne wchłanianie w jelicie cienkim większości aminokwasów osiągających z. treścią dwunastnicę wynosilo od 50 do $70 \%$ we wszystkich grupach, natomiast pozorne wchłanianie cysteiny było znacząco mniejsze ( 25 do $40 \%$ ). Ilość lizyny wchłanianej z jelita cienkiego u buhajków grupy I odpowiadała ilości pobranej z pasza, natomiast w grupie Il i III byla 2,4 i 3-krotnie, a metioniny dwukrotnie większa niż pobrancj, wskazując na wysoki stopień konwersji azotu dawki dla zwierząt grupy II i III w białko drobnoustrojów żwaczowych. 